\title{
Alignment of values and political orientations amplifies climate change attitudes and behaviors
}

\author{
E. Keith Smith • Lynn M. Hempel
}

Received: date / Accepted: date

\begin{abstract}
Anthropogenic climate change presents an immediate threat, necessitating a rapid shift in climate change relevant behaviors and public policies. A robust literature has identified a number of individual-level determinants of climate change attitudes and behaviors. In particular, political orientations and selftranscendent values are amongst the most consistent and substantive predictors. But, political orientations and individual values do not operate in isolation of each other, and rather are deeply related constructs. Accordingly, this analysis focuses on identifying the direct and interactive effects of political orientations and human values on climate change attitudes and behaviors. Adopting cross-national data from 16 Western European states (2016 ESS), we find that when in alignment, the effect of human values on climate change concern and policy support is amplified by political orientations. The moderating effect of political orientations is most substantive for self-transcendence (positive) and conservation (negative) values.
\end{abstract}

Keywords Climate Attitudes · Political Polarization · Human Values · Energy Preferences · Cross-national Data

\author{
E. Keith Smith \\ ETH Zurich, Haldeneggsteig 4 \\ IFW C 45.2 \\ 8092 Zürich, Switzerland \\ E-mail: keith.smith@gess.ethz.ch \\ Lynn M. Hempel \\ Department of Sociology, Colorado State University
}




\section{Introduction}

2 Anthropogenic climate change presents one of the greatest challenges facing the global community and necessitates fundamental changes in individual and collective relationships with the environment. International agreements, such as the 2017 Paris Accords, have set ambitious greenhouse gas reduction targets, largely aimed at limiting global mean temperature growth to under $2^{\circ}$. To meet such goals, rapid interventions are necessary to shift away from carbon-based schemes (Farmer et al., 2019). Public support plays a crucial role in facilitating the political and institutional changes necessary to shift to post-carbon, or reduced carbon-emissions, states (Baumgartner and Jones, 2010). Increased concern and activism about the effects of climate change can further spur new social and political coalitions aimed at mobilizing change and shift the priorities of existing coalitions (Sabatier, 1988; Weible and Sabatier, 2017). As such, understanding the social mechanisms that promote climate change concern and action remains pivotal to mobilizing the mass support needed to mitigate the existential threat climate change poses.

Political orientation is routinely found to be an important mechanism shaping climate change support. People with left-leaning political attitudes are comparatively more likely to be concerned about climate change, believe in anthropogenic climate change, be willing to support climate change policies than their counterparts (McCright et al., 2016b; Hamilton, 2011). Political polarization has further exacerbated this divide (McCright et al., 2016a; Lewis et al., 2018; MarquartPyatt et al., 2019), although the effects of polarization are more salient in the English-speaking states than Western European states (Smith and Mayer, 2018a).

A separate literature addresses the role of human values in shaping climate change attitudes and behaviors (Dietz et al., 2007; Poortinga et al., 2011, 2019). Broadly, individuals are found to vary on whether they view 'the environment' as having intrinsic value (as an end in itself), relational value (as something we are committed to and responsible for), or simply as having instrumental value (as a means to an end). People with more self-transcendent values are found more likely to engagement pro-environmental behaviors while those prioritizing selfenhancement values are less likely (Dietz et al., 2005; Katz-Gerro et al., 2017; Nordlund and Garvill, 2002; Steg and De Groot, 2012).

In brief, both human values and political orientations are found to be among the most important predictors of climate change concern (Hornsey et al., 2016). To date, however, the multiplicative relationship between human values and political orientations on climate change attitudes and behaviors remains largely unexplored.

This is a surprising omission given that human values and political orientations are thought to be deeply interrelated constructs, since values act as core building 
blocks of a person's political attitudes and behaviors (Rokeach, 1973; Converse, 1964; Piurko et al., 2011).

We address this omission here. The current study examines the independent and interactive effects of human values and political orientations on climate change concern, behaviors and policy support in Western European states using 2016 European Social Survey data and multilevel modeling approaches. We find that when values and political attitudes are in alignment, this consistency leads to an amplification in the effect on climate change attitudes and behaviors. That is, there is a multiplicative effect of values and politics.

The study makes an important contribution to the growing body of literature on cross-national climate change attitudes and behaviors, particularly within Western European states (McCright et al., 2016a; Lewis et al., 2018; Marquart-Pyatt et al., 2019; Poortinga et al., 2019; Smith and Mayer, 2018a) by identifying and advancing understanding of the relationship between two key social mechanisms in climate change support.

\section{Theoretical Background}

\subsection{Human Values}

Issues such as climate change "invoke fundamental question on how we ought to live and how humans should value and relate to each other and non-human nature" (Wardekker et al., 2009, p.513). Such questions direct attention to the sources of and patterns in underlying values and reasoning people use as they develop, evaluate, and justify responses to climate change (Feinberg and Willer, 2013; Gardiner, 2006). Values are thought of as internalized schemas that individuals draw upon to set the boundaries for what they consider acceptable (Hitlin and Piliavin, 2004). They structure and guide how people interpret and experience the social world and act within it (Joas, 2000). They also shape how an individual prioritizes what is important and what needs to be acted on in their lives. In short, values provide a framework for organizing actions and beliefs about climate change (Milfont et al., 2015).

The role of human values in shaping climate change attitudes and behaviors has been the subject of extensive previous research (see Poortinga et al., 2019; Corner et al., 2014; Dietz et al., 2007). However, researchers conceptualize and measure human values in different ways. Post-materialist perspectives, for example, suggest that as the socio-economic conditions shift towards greater prosperity, individual values increasingly focus on non-material goals, such as equality or environmentalism (Inglehart, 1977, 1995; Gelissen, 2007). The Values-Beliefs-Norms 
(VBN) literature identifies the role that altruistic, egoistic, and biospheric values play in shaping environmental attitudes and behaviors (Stern et al., 1999; Dietz et al., 2005).

The Schwartz value schema is the most widely used approach within the literature (Poortinga et al., 2019; Corner et al., 2014), largely due to the availability of robust measurement items and comparability across socio-cultural settings (Davidov et al., 2008; Davidov, 2008). Schwartz (1992) identified ten, broad, universal human values, which are each defined by the specific motivational goals that they represent. These values can be arranged into a circular continuum (see Figure 1) (Schwartz, 1992, 2012), in which the values are ordered by their compatibility/conflict.

Figure 1: Schwartz Human Values Schema with Higher Order Dimension

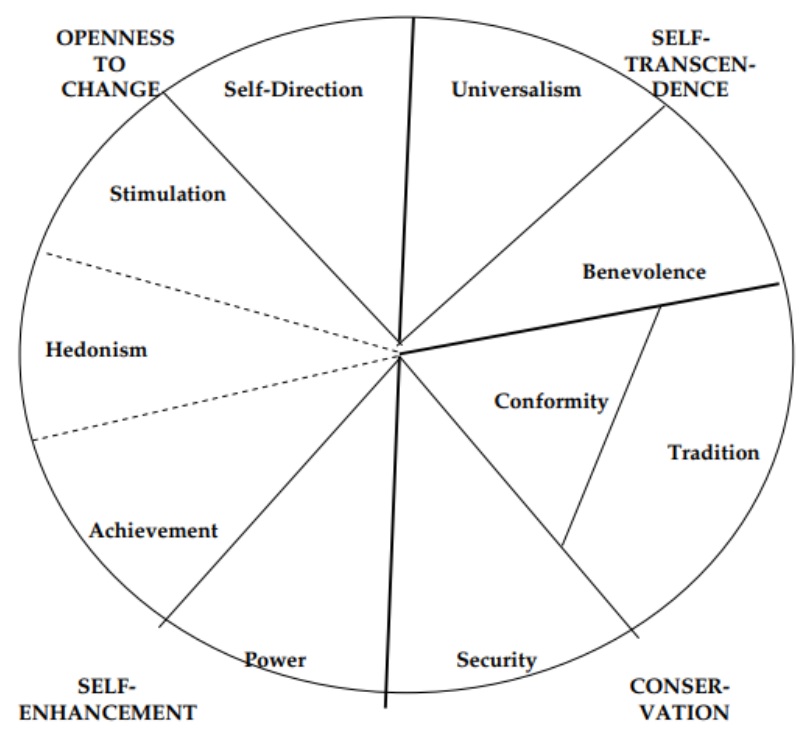

(Schwartz, 1992, 2012)

These ten values are organized into four higher order dimensions. Self-enhancement values (power and achievement) promotes self-interest, which is in opposition to self-transcendent values (universalism and benevolence), which prioritize the concern and welfare of others. Openness to change values (self-direction and stimulation) encourage change and openness to new ideas are in opposition to conservatism values (tradition, conformity and security), which emphasize maintenance of the status quo and stability. 
Previous studies adopting Schwartz's framework find that the four dimensions vary in their relationship to climate change support. Self-transcendent values have a strong positive relationship to climate change concern (Dietz et al., 2007; Corner et al., 2014), and are less associated with climate change skeptical beliefs (Steg and De Groot, 2012). In contrast, self-enhancement values are positively related to climate change skeptical views (Poortinga et al., 2011), and function to decrease the likelihood that a person will view climate change as dangerous (Poortinga et al., 2019). Openness to change values are also found to be negatively related to climate change skepticism, and increase the likelihood of negatively viewing the impact of climate change (Poortinga et al., 2019; Milfont et al., 2015), while conservation is found to be positively related to climate change skeptical beliefs (Poortinga et al., 2011).

Drawing upon this previous literature, we expect that:

Hypothesis I: The Schwartz human value dimensions of self-transcendence and openness to change will be positively related to climate change concern (1a), reducing energy usage (1b) and support for increased fossil fuels taxes (1c). While, alternatively, the value dimensions of self-enhancement and conservation will be negatively related.

\subsection{Political Orientations}

Political factors, such as orientation and party identification, have received substantial interest from previous scholarship for the role they play in shaping climate change attitudes, behaviors and policy support (McCright et al., 2016b). Political factors are broadly found to have a polarizing effect, where those on the political left are more likely to be concerned about climate change or be willing to support climate change policies than those on the right (McCright and Dunlap, 2011; Hoffman, 2011).

The theoretical causes of political polarization appear to be both individual and contextual. On the individual-level, the 'anti-reflexivity' hypothesis posits that individuals, groups, and politically-motivated organizations on the political right are more likely to be supportive of liberal, 'free-market' economic systems (McCright and Dunlap, 2010). Accordingly, those on the political right are more likely to reject the problems caused by the economic system, such as global climate change. The solution aversion hypothesis similarly suggests that those on the political right may be more likely to resist potential solutions to climate change, as they are likely to involve undesirable governmental intervention into previously unfettered markets (Campbell and Kay, 2014). 
At the group-level, political party identification can be understood as a form of social identity, setting boundaries for who is 'in' and 'out' of their group (Iyengar et al., 2012; Colvin et al., 2015). People develop a sense of belonging to an ingroup (Tajfel, 1978) and adopt group norms and attitudes (Weisberg and Greene, 2003; Brewer and Brown, 1998; Turner et al., 1994) - especially on salient issues (Unsworth and Fielding, 2014). Such intergroup processes generate greater concordance on salient issues as individual harmonize attitudes within the party. Furthermore, individual political attitudes are often shaped by elite members' cues (Cohen, 2003; Malka and Lelkes, 2010; Tesler, 2017). Elite conservatives and groups, most notably in English-speaking states, have engaged a decades long messaging campaign to shifting public opinion against climate change policies and measures (McCright and Dunlap, 2003, 2011; Oreskes and Conway, 2011) which has been amplified by media outlets (Feldman et al., 2012; Hmielowski et al., 2014). Recent studies empirical studies have found a substantive effect of elite cues driving attitudes towards climate change in the US (Brulle et al., 2012; Farrell, 2016). People are responsive to elite cues from party elites and shape their attitudes to be in line with the in-group, a process that has been called 'identity protective cognition'(Kahan, 2015, 2017).

The climate change skeptic counter-movement largely originated in Englishspeaking states (McCright and Dunlap, 2003; Oreskes and Conway, 2011), however recent literature has begun to question whether political polarization of climate change attitudes and behaviors is a global phenomenon, or rather one limited to Anglophone states where processes of political polarization and elite mobilization against climate change measures are more pronounced. While there does appear to be political polarization in climate change concerns and policy support in Western European states, the substantive effect is more pronounced in English-speaking states (Smith and Mayer, 2018a; Lewis et al., 2018).

Based upon these recent findings, we expect that:

Hypothesis II: People with left-leaning political orientations will be more likely than those with politically right-leaning orientations to be concerned about climate change (2a), willing to reduce their energy usage (2b) and support increased fossil fuels taxes (2c) (see McCright et al., 2016a; Smith and Mayer, 2018a).

\subsection{Human Values and Political Orientations}

Human values are found to play a central role in shaping an individual's political orientations and beliefs (Caprara and Zimbardo, 2004; Feldman, 1988). Values act as the building blocks of political orientations and dispositions (Rokeach, 1973; 
Converse, 1964), where they are drawn upon to organize and prioritize political beliefs and decisions (Piurko et al., 2011). People prefer political ideologies, parties and policies that align with their core values, as well as those that protect their values against perceived threats (Barnea and Schwartz, 1998; Schwartz et al., 2010). For example, people that prioritize openness to change values are found to be more supportive of individual freedoms and civil rights, while those that prioritize self-enhancement values prefer non-egalitarian policies and are against government interventions (Piurko et al., 2011). As such, political factors and human values are thought not to exist in isolation of each other, but rather to be closely entwined.

Several studies provide correlational evidence of the close relationship between values and political orientation. Caprara and colleagues, for example, observe that self-transcendence values (namely universalism) are associated with political left orientations, while conservation values (security and tradition) are closely linked with right orientations (Caprara et al., 2017). Politically left ideologies can be characterized by open-mindedness, mental flexibility, and commitment to social and economic equality, while politically right ideologies commonly stress the importance of resistance to change as well as work towards justifying inequalities (Jost et al., 2003). Using data from the European Social Survey, Aspelund et al. Aspelund et al. (2013) and Piurko et al. Piurko et al. (2011) also find that conservation and self-enhancement values are positively related to right-leaning ideologies in Western European states, while self-transcendence is closely linked to politically left orientations, while the relationship between openness to change values and specific political orientations is less clear.Using cross-national data from 15 states, Caprara et al. Caprara et al. (2017) report a similar pattern in the relationship between human values and political orientations.

The relationship between political orientation and human value likely reflects people's strong desire for cognitive consistency; that is, people want their beliefs, opinions, and attitudes to be congruent (Festinger, 1957). Cognitive (in)consistency serves as a cue about the correctness of a person's belief system (Gawronski, 2012; Quine and Ullian, 1978): the more congruent, the more correct people perceive their views to be. We argue that when an important value aligns with a person's political orientation, this acts as a reinforcing mechanism on the validity of one's beliefs. The alignment of personal values and political orientation amplifies climate change support by reinforcing confidence in the correctness of their position. Conversely, when values and political orientations are not in alignment, there may be uncertainty and ambiguity about the correctness of a position.

As such, we anticipate that when an individual's values and political attitudes are in alignment towards a specific social issue, they can interact, and even amplify, the person's attitude or response towards this issue. For example, self-enhancement 
values have a positive relationship with climate change skeptical views (Dietz et al., 2005; Poortinga et al., 2019), as well as with right leaning political orientations (Caprara et al., 2006; Schwartz et al., 2010), while further, right leaning political orientations is also positively related to climate change skepticism (Smith and Leiserowitz, 2012; McCrea et al., 2016). In this exemplary case, a person's values and politics would be in alignment with their climate change skeptic belief, and through this self-reinforcement could interact to amplify their beliefs. Alternatively, if a person's values and politics are not in alignment, they could act as a dampening effect. We therefore expect that:

Hypothesis III: When value dimensions and political orientations are in alignment, the interactive effect will be amplified on concerns for climate change (3a), willingness to reduce energy usage (3b) and support for increased fossil fuels taxes (3c).

\section{Data}

For this analysis, we adopt recent survey data from the 2016 European Social Survey (ESS), Wave 8 European Social Survey (2016b). This wave includes a special module on public attitudes towards climate change. Further, the ESS contains the Portrait Values Questionnaire (PVQ) indicators as part of its core module indicators, capturing the Schwartz Values Schema. As such, the 2016 ESS presents an entirely unique data set, allowing for cross-national comparisons to be made of the effect of values on climate change attitudes.

Data was collected in the latter half of 2016, primarily using CAPI and faceto-face interviews. The 2016 ESS covers the following 16 Western European states: Austria, Belgium, Finland, France, Germany, Great Britain, Iceland, Ireland, Israel, Italy, Netherlands, Norway, Portugal, Sweden, Spain, Switzerland. Within country response rates ranged from $30.6 \%$ in Germany to $73.4 \%$ (Israel). The smallest number of completions was 880, in Iceland, while for most nations over 1,500 respondents completed the survey (European Social Survey, 2016a). The 2016 ESS contains as special module, 'Public Attitudes to Climate Change, Energy Security, and Energy Preferences' including several items assessing components related to climate change.

While political polarization is amongst the strongest, and most studied determinants of climate change attitudes (Hornsey et al., 2016; McCright et al., 2016b), the effect of political polarization appears to be concentrated within English speaking and Western European states (Lewis et al., 2018; McCright et al., 2016a; Marquart-Pyatt et al., 2019). Further, Smith and Mayer (2018a) suggest 
that the effects of political polarization, while smaller, may be in the opposite direction in transition states. That is, individuals on the political right are more likely to perceive climate change as a danger than those on the left. This suggests that there may be "differing meanings" of political left-right placement in transition states (McCright et al., 2016a). In Western European states, right of center parties often support policies that limit government intrusion into markets and are deregulatory in nature, while the opposite is true in transition states. In transition states, right leaning parties often support economic liberalization and free-market policies, while those on the political left are often more closely associated with previous state socialist policies and regimes. As such, while the ESS also contains data from transition states, our analysis focuses primarily on the more established effects of political attitudes within these 16 Western European states.

\subsection{Outcome Variables}

Climate change attitudes and behaviors encompass multiple diverse constructs, such as skepticism (a specific belief), concern (a measure of risk perception), individual or collective behaviors and policy support. While these constructs may be interrelated - i.e. climate skepticism is negatively related to climate change concern (Engels et al., 2013; Tranter and Booth, 2015), concern is positively related to climate change policy support (Spence et al., 2011; Drews and Bergh, 2016; Egan and Mullin, 2017) - each contains their own unique components and subdimensions, and often have their own unique set of theoretical drivers (McCright et al., 2016b; Smith et al., 2018). Climate skepticism has multiple components, such a disbelief in the trends, attribution and impact of climate change (Roser-Renouf and Nisbet, 2008). Environmental concerns result from a complex combination of individual experiences and structural forces, such as cultural factors, media framing and political activism (Auyero and Swistun, 2008; Kasperson et al., 1988; Malin, 2015). Similarly, van der Linden van der Linden (2015) suggests that climate change risk perceptions are products of cognitive factors (knowledge), experiential processing (such as emotions and personal experiences), sociocultural influences (norms, value orientations) and socio-demographics. While Stern Stern (2000) defines 'environmentally significant' behaviors as actions that have an impact on the environment, in one form or another, which can be separated into four distinct types: environmental activism (participation in social movements), non-activist behaviors in the public sphere (policy support, petitions), private-sphere environmentalism (individual, 'pro-environmental' actions), and other environmentally significant behaviors (actions in the workplace). For this analysis, we adopt a multiple indicator 
approach, to best capture three different dimensions of climate change attitudes and behaviors: climate change concern, individual behaviors and policy support.

First, climate change concern is measured by respondents ranking their worry for climate change from 1 'not at all worried' to 4 'very/extremely worried'. This item is originally coded from 1 to 5 , but we collapsed values 4 'very' and 5 'extremely' together due to concerns about data sparsity for the 'extremely worried' response (5\% of responses). Second, individual behaviors is measured by an indicator of environmental action, reduce energy, which measures how often the respondent does things to reduce energy usage, from 1 'never' to 6 'always'. Third, we include an indicator of climate change policy support, increase fossil fuel taxes, where the respondent rates their favor of increase taxes on fossil fuels to reduce climate change from 1 'strongly against' to 4 'somewhat/strongly favor'. This item is originally coded from 1 to 5 , but we collapsed values 4 'somewhat' and 5 'strongly' together due to concerns about data sparsity for the 'strongly favor' response $(8 \%$ of responses) . Distributions for these variables are displayed in Figure 2.

Figure 2: Distribution of Responses for Dependent Variables
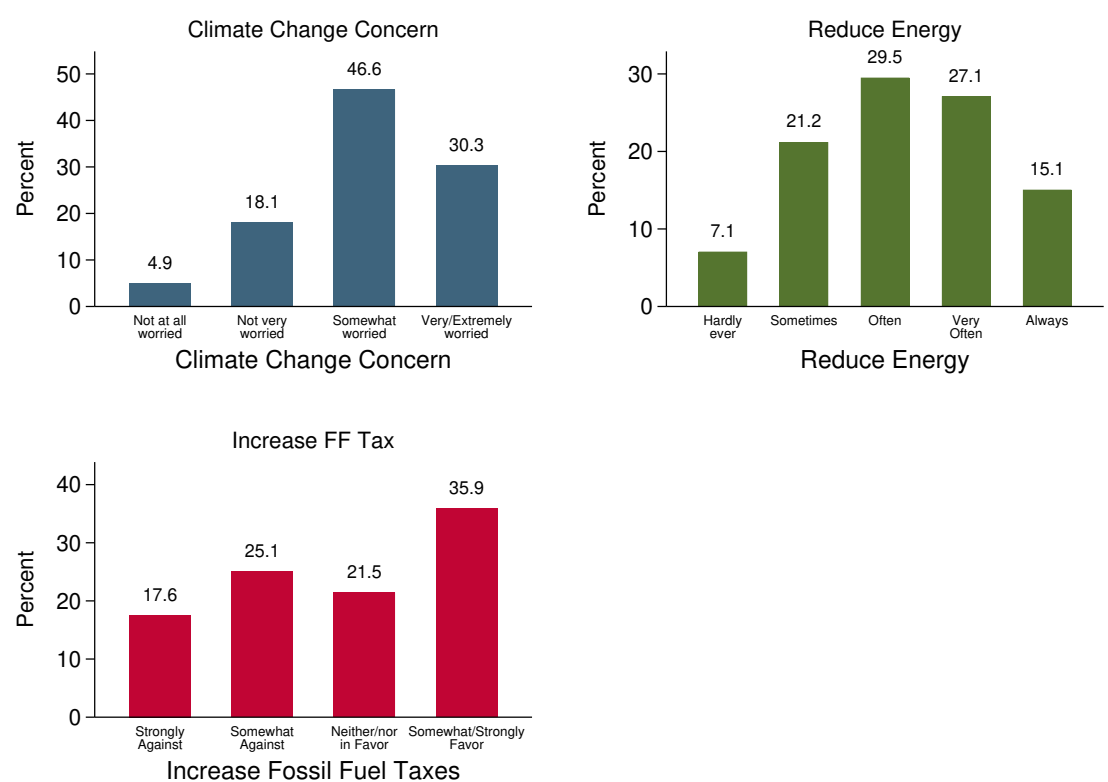


\subsection{Predictor Variables}

The analysis focuses on identifying the independent and interactive effect of human values and political orientation on the three components of climate change concern, behavior and policy support. First, human values are identified using the modified 21-item version of the Portrait Values Questionnaire (PVQ) adapted for the ESS (Schwartz, 2003). To measure the 10 Schwartz values, each item presents a short sentence, a portrait, of a gender-matched person. Then, the respondent is tasked with ranking how much this person is 1 'not like me at all' to 6 'very much like me'. Due to concerns of multicollinearity and parsimony, these 10 values are collapsed into scales representing the 4 higher-order dimensions. The items for universalism and benevolence are combined into the 'self-transcendence' dimension ( $\alpha=0.72$ ), while the items for power and achievement are included in the scale for 'self-enhancement' $(\alpha=0.72)$. Next, 'conservation' is derived from the items for conformity, tradition and security $(\alpha=0.70)$ and lastly, stimulation and selfdirection are combined into the dimension 'openness to change' $(\alpha=0.63)$ (see Supplementary Table S1).

Political orientation is measured based on self-placement on a political right to left scale. Respondents are ranked from holding view that range from 1 'strong right' to 3 'moderate' to 5 'strong left'. Political orientation is adopted over other alternative measures, such as party identification, to allow for better cross-national comparability of political beliefs.

\subsubsection{Control Variables}

Prior cross-national research has noted multiple correlates of climate change attitudes and behaviors on the individual and contextual-level, which we accordingly adopt as control variables for this analysis. Recent literature suggests that climate change attitudes and behaviors are affected by different constructs of trust (Fairbrother et al., 2019; Smith and Mayer, 2018b; Harring, 2014). For this analysis, we include two constructs of trust, social trust and a scale for political trust $(\alpha=0.88)$. Beliefs in adaptive capacity, that is the likelihood that individuals or groups will work to resolve climate change, is also noted as an important predictor of climate change behaviors and policy support (Mayer and Smith, 2018; Feinberg and Willer, 2011). We therefore include indicators for Individual Efficacy and Group Efficacy. Further, religious belonging has been found to be related to cross-national climate change attitudes (Lee et al., 2015). We therefore include indicators for religious belonging and religious service attendance. Lastly, we include indicators for socio-demographic variables common to studies of climate change, gender, age, educational attainment, and household income. 
Figure 2: Correlation Matrix of Dependent and Predictor Variables

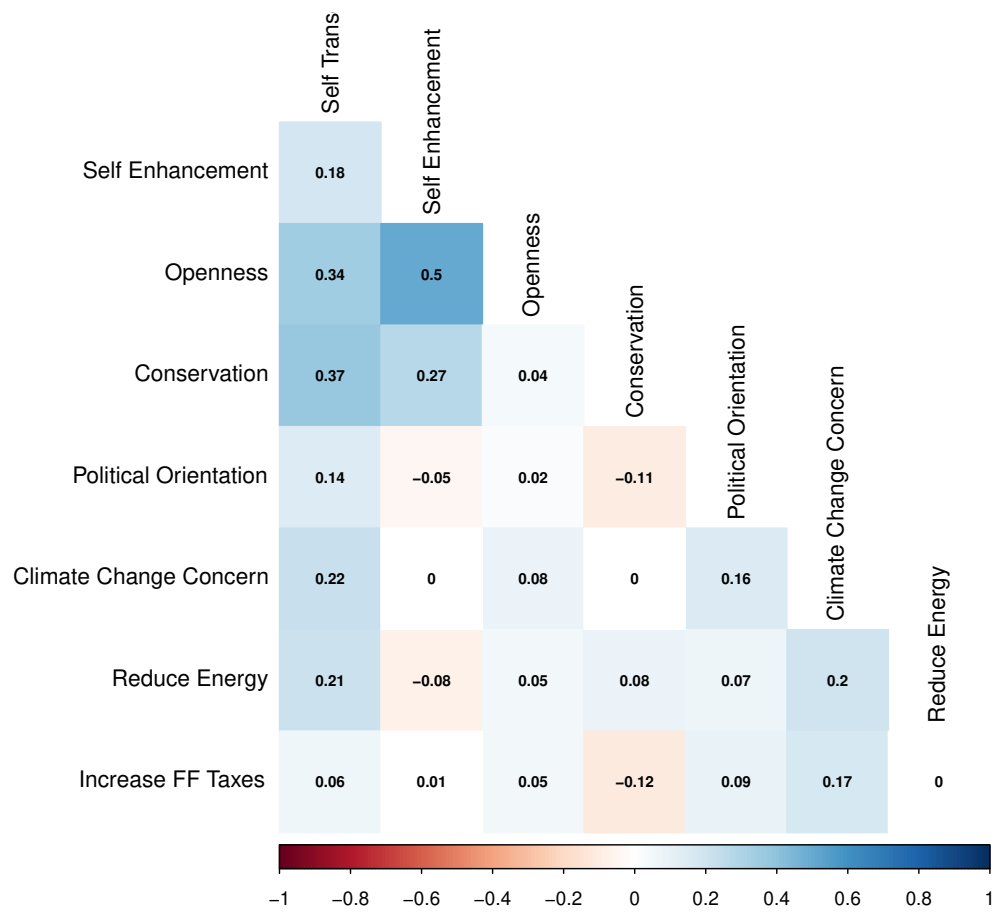

On the contextual-level, we include GNI per capita (World Bank, Atlas method 2016) to measure country wealth, an indicator for coal as a percentage of the total primary energy supply for each country (International Energy Agency, 2016), and a measure of freedom of expression, adapted from the Varieties of Democracy Index.

The descriptive statistics, original items, and variable coding for all the variables are presented in Table 1. Potential forms of multicollinearity were investigated in supplementary analyses, with all key predictors and control variables having a VIF of under 1.6.

\section{Methods}

Given the ordered nature of the three dependent variables, we adopt an ordered logistic regression approach appropriate to these indicators. The data is structured where individuals are nested within 16 diverse countries. As these observations are not considered to be independent, traditional regression approaches are not appropriate. As such, we adopt multi-level logistic modelling techniques which allow 
the intercepts to randomly vary across the countries (also known as random effect or mixed models). We estimate two regression models for each of the dependent variables. First, with the 'main effects' of the higher-order value dimensions and political orientation, and second with the interaction product term included.

Coefficients on the logistic scale are notoriously difficult to interpret. Further, focusing solely on statistical significance can lead to false conclusions or misinterpretation of results (Amrhein et al., 2019). We adopt an approach focusing on predicted probabilities (Long and Freese, 2014; Mood, 2010). For the 'main effects' models, we calculate predicted probabilities for the effects human values and political orientations holding control variables at their observed values and averaging the probabilities for each score of the focal predictor variables (Hypotheses 1 and 2 ). Given that human values are continuous scales with non-inherently substantive quantities, we predicted values at the 5th percentile ('low'), median ('moderate') and 95th percentile ('high') for each of the four human value dimensions. For political orientation, predicted probabilities are calculated for all five ordered values of this item.

Lastly, we address how the effects of political orientation may be amplified by the human values dimensions (Hypothesis 3) via adoption of a product-term interaction. The interaction analyses focus on identifying potential amplifying, moderating effect, which investigates if and how the strength and direction of relationship between $x$ and $y$ changes due to a third variable, $z$. To identify patterns of amplification, the same values are used to calculate the human values* political orientation predictions in the 'interaction models' (Hypothesis 3). All probabilities predict the highest outcome for each of the dependent variables. In order to understand the effect of an interaction term with non-linear outcomes, coefficients of the product term do not provide sufficient information on the significance, magnitude of direction of this interaction (Mize, 2019). As such, we again adopt predicted probabilities to determine the nature of these interactive effects (Brambor et al., 2006). 


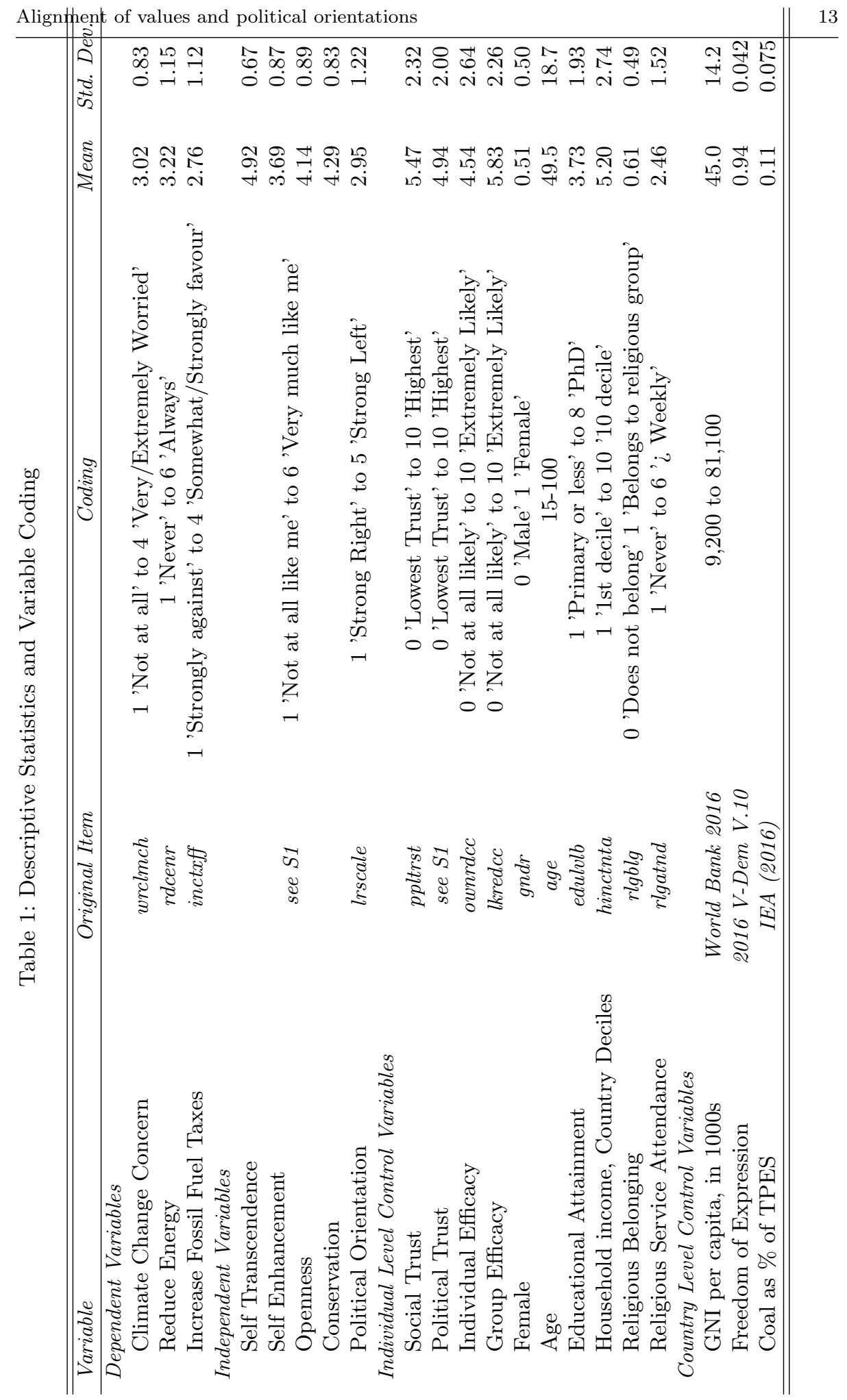


Figure 4: Predicted Probabilities of key predictors, main effects. Predicted probability calculated at highest value of dependent variables. Fixed effects only, calculated holding all other predictors in Table 2 at their means.

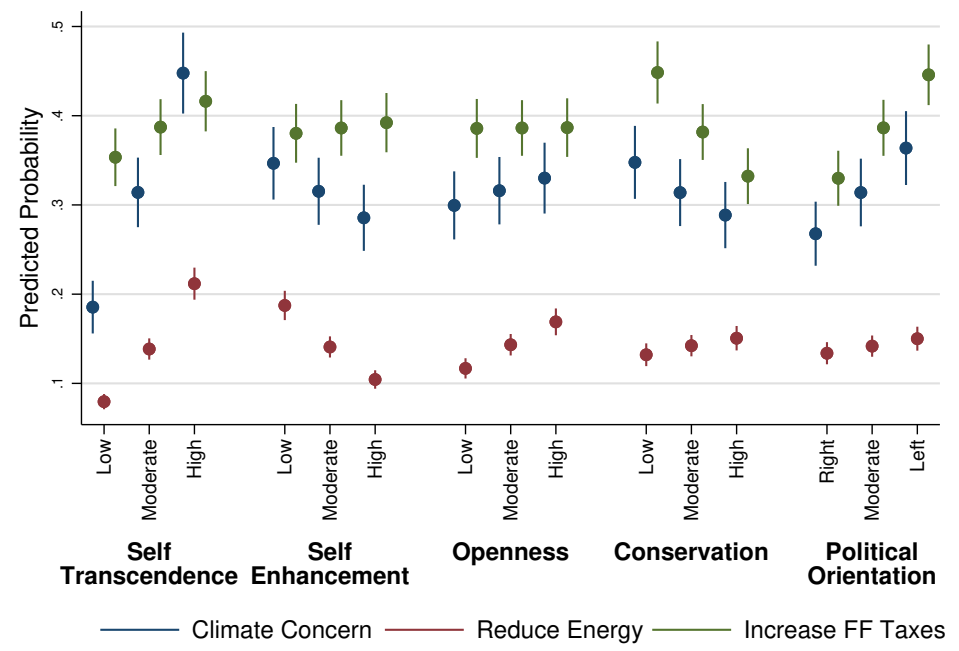

\section{Results}

The following sections presents the results from the multilevel ordered logistic regression analysis separately for the effects of human values dimensions and political orientations on climate change concern, reducing energy and increase fossil taxes. We first test for the effects of human values dimensions and political orientations on climate change concern, reducing energy and increase fossil taxes, where we anticipate that dimensions of self-transcendence and openness to change will be positively related to these outcomes and the value dimensions of self-enhancement and conservation will be negatively related (Hypothesis 1). Further, people with politically left orientations are expected to have greater climate change concern, reduce energy usage for climate change and support increasing fossil fuel taxes more than those on the political right (Hypothesis 2). The regression results for the analysis are presented in Table 2, while the predicted probabilities for the main effects of the key predictors are displayed in Table ??.

Next, we investigate whether the human values dimension potentially moderate or mediate the effect of political orientation on climate change concern, reducing energy and increase fossil taxes. To investigate for amplification, we adopt an interaction product term approach, with the predicted probabilities for the interaction plotted in Figure 5. 
Table 2: Multilevel Ordered Logistic Regression Results

\begin{tabular}{|c|c|c|c|c|c|c|}
\hline & \multicolumn{2}{|c|}{$\begin{array}{c}\text { Climate Change } \\
\text { Concern }\end{array}$} & \multicolumn{2}{|c|}{$\begin{array}{l}\text { Reduce } \\
\text { Energy }\end{array}$} & \multicolumn{2}{|c|}{$\begin{array}{c}\text { Increase Fossil } \\
\text { Fuel Taxes }\end{array}$} \\
\hline & Base & Int. & Base & Int. & Base & Int. \\
\hline \multirow[t]{2}{*}{ Self Transcendence } & $0.63^{* *}$ & $0.39^{* *}$ & $0.53^{* *}$ & $0.51^{* *}$ & $0.13^{* *}$ & -0.04 \\
\hline & $(0.03)$ & $(0.06)$ & $(0.02)$ & $(0.06)$ & $(0.02)$ & $(0.06)$ \\
\hline \multirow[t]{2}{*}{ Self Enhancement } & $-0.12^{* *}$ & 0.00 & $-0.27^{* *}$ & $-0.26^{* *}$ & 0.02 & 0.05 \\
\hline & $(0.02)$ & $(0.05)$ & $(0.02)$ & $(0.05)$ & $(0.02)$ & $(0.05)$ \\
\hline \multirow[t]{2}{*}{ Openness } & $0.06^{* *}$ & -0.03 & $0.16^{* *}$ & 0.04 & 0.00 & -0.07 \\
\hline & $(0.02)$ & $(0.05)$ & $(0.02)$ & $(0.05)$ & $(0.02)$ & $(0.05)$ \\
\hline \multirow[t]{2}{*}{ Conservation } & $-0.12^{* *}$ & 0.08 & $0.06^{* *}$ & 0.07 & $-0.20^{* *}$ & 0.07 \\
\hline & $(0.02)$ & $(0.05)$ & $(0.02)$ & $(0.05)$ & $(0.02)$ & $(0.05)$ \\
\hline \multirow[t]{2}{*}{ Political Orientation } & $0.13^{* *}$ & 0.00 & $0.03^{* *}$ & -0.15 & $0.14^{* *}$ & 0.16 \\
\hline & $(0.01)$ & $(0.10)$ & $(0.01)$ & $(0.09)$ & $(0.01)$ & $(0.09)$ \\
\hline \multirow[t]{2}{*}{ Social Trust } & $-0.04^{* *}$ & $-0.04^{* *}$ & $-0.03^{* *}$ & $-0.03^{* *}$ & $0.03^{* *}$ & $0.03^{* *}$ \\
\hline & $(0.01)$ & $(0.01)$ & $(0.01)$ & $(0.01)$ & $(0.01)$ & $(0.01)$ \\
\hline \multirow[t]{2}{*}{ Political Trust } & -0.01 & -0.01 & $-0.03^{* *}$ & $-0.03^{* *}$ & $0.14^{* *}$ & $0.14^{* *}$ \\
\hline & $(0.01)$ & $(0.01)$ & $(0.01)$ & $(0.01)$ & $(0.01)$ & $(0.01)$ \\
\hline \multirow[t]{2}{*}{ Individual Efficacy } & $0.10^{* *}$ & $0.10^{* *}$ & $0.04^{* *}$ & $0.04^{* *}$ & $0.09^{* *}$ & $0.09^{* *}$ \\
\hline & $(0.01)$ & $(0.01)$ & $(0.01)$ & $(0.01)$ & $(0.01)$ & $(0.01)$ \\
\hline \multirow[t]{2}{*}{ Group Efficacy } & $0.17^{* *}$ & $0.17^{* *}$ & $0.06^{* *}$ & $0.06^{* *}$ & $0.10^{* *}$ & $0.10^{* *}$ \\
\hline & $(0.01)$ & $(0.01)$ & $(0.01)$ & $(0.01)$ & $(0.01)$ & $(0.01)$ \\
\hline \multirow[t]{2}{*}{ Female } & $0.09^{* *}$ & $0.09^{* *}$ & $0.05^{*}$ & $0.05^{*}$ & 0.04 & 0.04 \\
\hline & $(0.03)$ & $(0.03)$ & $(0.03)$ & $(0.03)$ & $(0.03)$ & $(0.03)$ \\
\hline \multirow[t]{2}{*}{ Age } & $-0.00^{* *}$ & $-0.00^{* *}$ & $0.01^{* *}$ & $0.01^{* *}$ & $-0.00^{* *}$ & $-0.00^{* *}$ \\
\hline & $(0.00)$ & $(0.00)$ & $(0.00)$ & $(0.00)$ & $(0.00)$ & $(0.00)$ \\
\hline \multirow[t]{2}{*}{ Educational Attainment } & $0.07^{* *}$ & $0.07^{* *}$ & $0.08^{* *}$ & $0.08^{* *}$ & $0.11^{* *}$ & $0.10^{* *}$ \\
\hline & $(0.01)$ & $(0.01)$ & $(0.01)$ & $(0.01)$ & $(0.01)$ & $(0.01)$ \\
\hline \multirow[t]{2}{*}{ Household income, Country Deciles } & 0.01 & 0.01 & $-0.02^{* *}$ & $-0.02^{* *}$ & $0.03^{* *}$ & $0.03^{* *}$ \\
\hline & $(0.01)$ & $(0.01)$ & $(0.01)$ & $(0.01)$ & $(0.01)$ & $(0.01)$ \\
\hline \multirow[t]{2}{*}{ Religious Belonging } & -0.06 & -0.06 & -0.05 & -0.05 & $-0.15^{* *}$ & $-0.14^{* *}$ \\
\hline & $(0.03)$ & $(0.03)$ & $(0.03)$ & $(0.03)$ & $(0.03)$ & $(0.03)$ \\
\hline \multirow[t]{2}{*}{ Religious Service Attendance } & 0.01 & 0.01 & -0.00 & -0.01 & $0.05^{* *}$ & $0.05^{* *}$ \\
\hline & $(0.01)$ & $(0.01)$ & $(0.01)$ & $(0.01)$ & $(0.01)$ & $(0.01)$ \\
\hline \multirow[t]{2}{*}{ GNI per capita, in 1000 s } & $-0.02^{* *}$ & $-0.02^{* *}$ & $-0.01^{*}$ & $-0.01^{*}$ & $0.01^{*}$ & $0.01^{*}$ \\
\hline & $(0.01)$ & $(0.01)$ & $(0.00)$ & $(0.00)$ & $(0.01)$ & $(0.01)$ \\
\hline \multirow[t]{2}{*}{ Freedom of Expression 2016} & 4.89 & 4.96 & $4.67^{* *}$ & $4.74^{* *}$ & -0.81 & -0.78 \\
\hline & $(2.89)$ & $(2.86)$ & $(1.41)$ & $(1.40)$ & $(2.15)$ & $(2.19)$ \\
\hline \multirow[t]{2}{*}{ Coal as $\%$ of TPES } & -0.25 & -0.25 & 0.87 & 0.87 & 0.00 & -0.01 \\
\hline & $(1.67)$ & $(1.66)$ & $(0.81)$ & $(0.80)$ & $(1.24)$ & $(1.27)$ \\
\hline Self Transcendence $\times$ Political Orientation & & $0.08^{* *}$ & & 0.01 & & $0.06^{* *}$ \\
\hline & & $(0.02)$ & & $(0.02)$ & & $(0.02)$ \\
\hline Self Enhancement $\times$ Political Orientation & & $-0.04^{* *}$ & & -0.00 & & -0.01 \\
\hline & & $(0.02)$ & & $(0.01)$ & & $(0.02)$ \\
\hline Openness $\times$ Political Orientation & & $0.03^{*}$ & & $0.04^{* *}$ & & 0.02 \\
\hline & & $(0.02)$ & & $(0.01)$ & & $(0.02)$ \\
\hline Conservation $\times$ Political Orientation & & $-0.06^{* *}$ & & -0.00 & & $-0.09^{* *}$ \\
\hline & & $(0.02)$ & & $(0.01)$ & & $(0.01)$ \\
\hline Variance Component & $0.15^{* *}$ & $0.15^{* *}$ & $0.03^{* *}$ & $0.03^{*}$ & $0.08^{* *}$ & $0.09^{* *}$ \\
\hline Observations & 21,337 & 21,337 & 21,305 & 21,305 & 21,182 & 21,182 \\
\hline $\mathrm{AIC}$ & 44078.5 & 44041.2 & 61117.4 & 61112.9 & 52463.5 & 52424.5 \\
\hline $\mathrm{BIC}$ & 44253.8 & 44248.3 & 61300.7 & 61328.0 & 52638.6 & 52631.5 \\
\hline
\end{tabular}

errors in parentheses

${ }^{*} p<0.05,{ }^{* *} p<0.01$ 
5.1 Climate Change Concern

\subsubsection{Main Effects}

The regression coefficients of the multilevel ordinal logistic regression are displayed in Table 2. The four human values dimensions all have significant effects on climate change concern. Self-transcendence $(b=0.63, p \leq 0.05)$ and openness to change values $(b=0.06, p \leq 0.05)$ have a positive significant effect on climate change concern, while self-enhancement $(b=-0.12, p \leq 0.05)$ and conservation $(b=-0.12, p \leq 0.05)$ have significant, negative effects. While political orientation $(b=0.13, p \leq 0.05)$ also has a significant, positive effect, meaning that people become more concerned about climate change as they move from the political right to left. All of these results are in the expected directions, providing support for Hypotheses $1 \mathrm{a}$ and $2 \mathrm{a}$.

Table ?? displays the predicted probabilities of people being extremely worried about climate change. Self-transcendence appears to have the largest substantive effect. People at the lowest levels of self-transcendence values have a predicted probability of 0.19 of being extremely worried about climate change, while this increases to 0.45 for people at the highest levels of self-transcendence. Self-enhancement and conservation also appear to have moderate, negative effects. Political orientation also appears to be a substantive predictor of climate change concern, with people on the right having a predicted probability of 0.27 of being extremely worried, compared to a predicted probability of 0.36 for those on the political left.

\subsubsection{Amplification}

To identify forms of amplification of human values and political orientation, we turn to Figure 5. The effect of the four human values dimensions all appear to be moderated by political orientation. The greatest amplification appears to be for self-transcendence, where the effect of this value is greatly amplified as people move from the political right to left. These findings appear to indicate that when self-transcendence values are in alignment with left leaning political ideologies, there is an amplification effect in the levels of climate change concern. Similar patterns are also evident for openness to change, but the effect size appears to be comparatively smaller. For self-enhancement and conservation, the amplification effect appears to be most noticeable at lower levels of the values. Given that these value dimensions are generally in opposition to political left leaning preferences, this finding means that for people who have lower levels of self-enhancement and 
conservation there is an amplifying effect. We therefore find evidence in support of Hypothesis 3a.

\subsection{Reduce Energy}

\subsubsection{Main Effects}

Next turning to the frequency that an individual reduces their energy usage, all four of the human values dimensions are found to have significant effects (again see Table 2). The coefficients of self-transcendence $(b=0.53, p \leq 0.05)$, selfenhancement $(b=-0.27, p \leq 0.05)$ and openness to change $(b=0.16, p \leq 0.05)$ are all in the expected direction, providing evidence in support of Hypothesis 1b. But, the coefficient for conservation values is positive $(b=0.06, p \leq 0.05)$, a surprising finding as these values are theorized to be in opposition to openness to change (which also has a positive coefficient). Lastly, the effect of political orientation is significant and positive $(b=0.03, p \leq 0.05)$, providing evidence in support of Hypothesis 2b.

While all the effects of these key predictors are significant, not all of them appear to have substantive effects (see Table ?? for predicted probabilities). The largest substantive effects are resultant of self-transcendent values, where there is a 0.13 difference in the predicted probability between between high (0.21) and low (0.08) levels of self-transcendent values. Self-enhancement also appears to have a moderate substantive effect, where people with high quantities of this value have a 0.10 predicted probability of always reducing their energy usage, compared to 0.19 for those with lower quantities of self-enhancement values. But, while conservation and political orientation both have significant coefficients, the substantive effect of these predictors on an individual always reducing their energy use appears to be limited.

\subsubsection{Amplification}

Figure 5 displays the interactions between human values dimensions and political orientation. Of these interactions, only the effect of openness to change appears to be moderated by political orientations on a person always reducing their energy usage. There are minimal differences between people on the political right, but these differences increase substantially as people more politically left leaning. This provides evidence of an amplifying effect when political orientations are in alignment with openness to change values. There is little visual evidence of a moderating effect for the other human values dimensions. Accordingly, we find limited evidence in support of Hypothesis 3b. 
Figure 5: Predicted Probabilities of Values by Political Orientation Interaction. Predicted probability calculated at highest value of dependent variables. Fixed effects only, calculated holding all other predictors in Table 2 at their means.

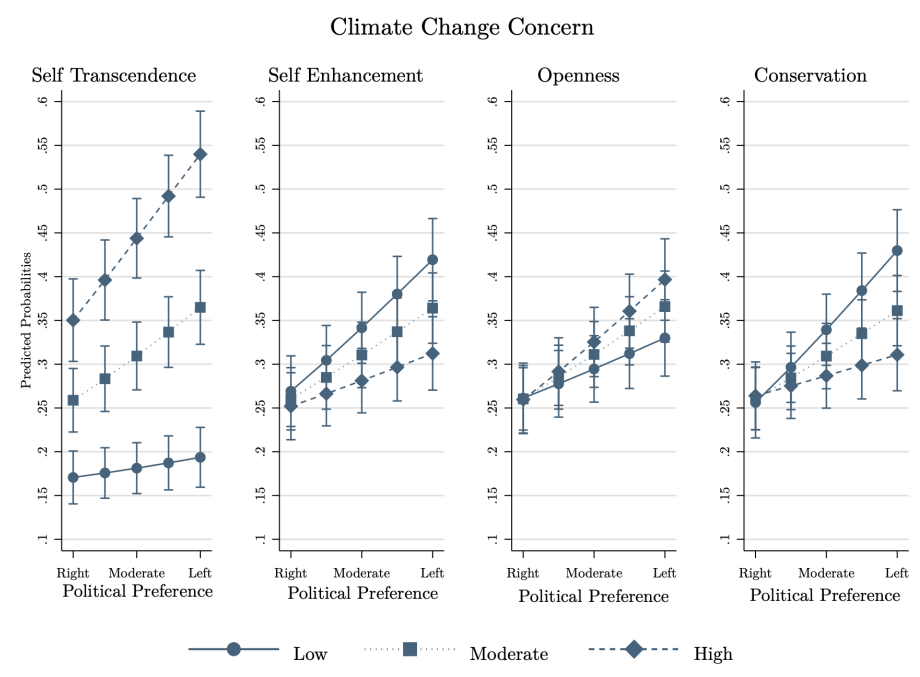

Reduce Energy

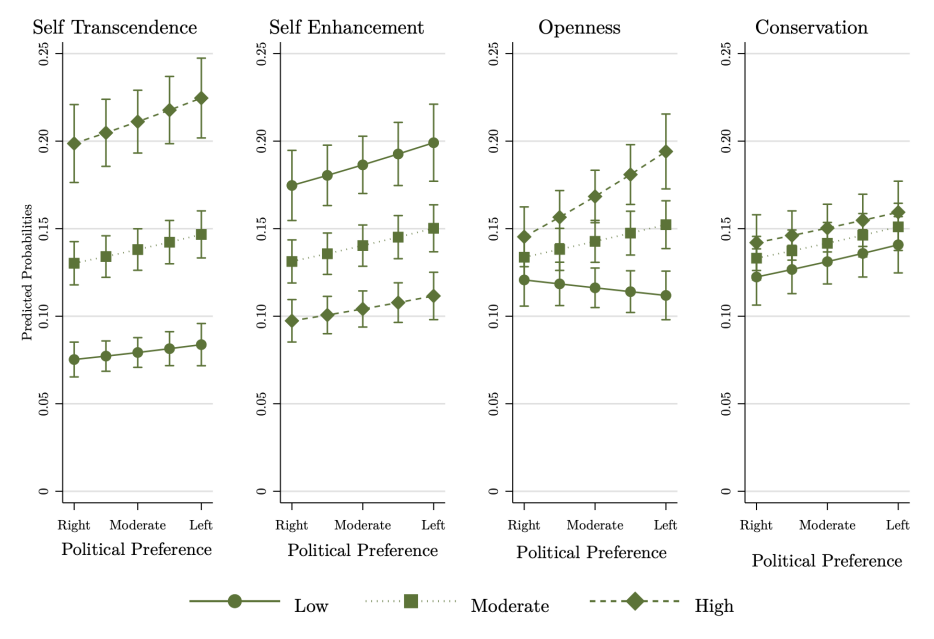

Increase Fossil Fuel Taxes

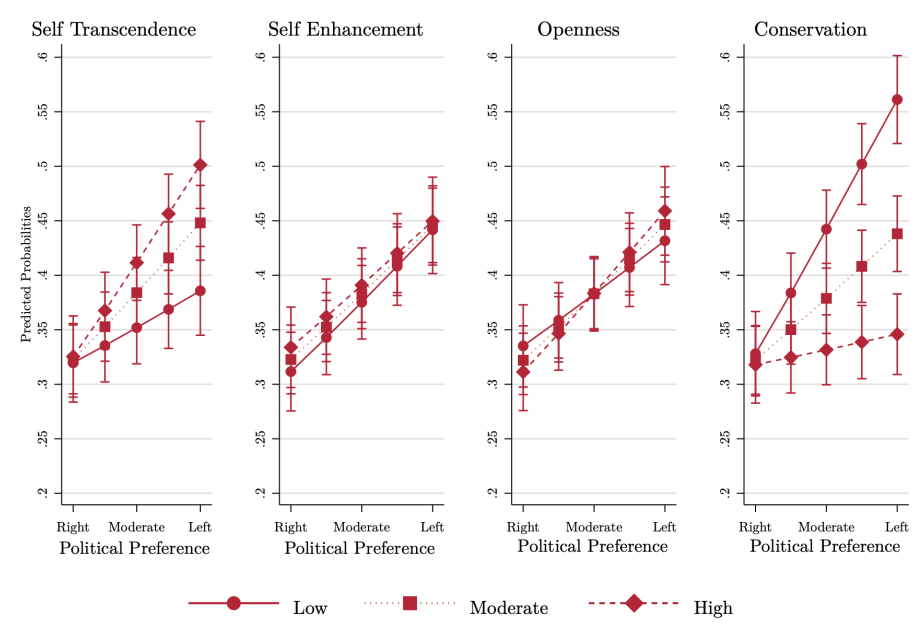


5.3 Increase Fossil Fuel Tax

\subsubsection{Main Effects}

Returning to the regression coefficients of the multilevel ordinal logistic regression in Table 2, We find that self-transcendence has a positive, significant effect on support for increased fossil fuel taxes $(b=0.13, p \leq 0.05)$, while conservation has a negative effect $(b=-0.20, p \leq 0.05)$. But neither self-enhancement $(b=0.02, n . s$. $)$ or openness to change $(b=0.00, n . s$. $)$ have a significant effect. As such, we find limited evidence in support of Hypothesis 1c. Political preference was again found to have a positive, significant on support for increased fossil fuel taxes $(b=0.14, p \leq$ 0.05 ), and we therefore find support for Hypothesis 2c.

Turing to predicted probabilities, the most substantive predictors appear to be political orientation and conservation. People on the political left have a 0.45 predicted probability of strongly supporting increasing fossil fuel taxes, compared to 0.33 for those on the right. While people with high quantities of conservation values have a 0.45 predicted probability, compared with 0.33 for those with low quantities. Self-transcendence values also appear to have positive effect, albeit substantively more moderate. Lastly, neither self-enhancement nor openness to change appear to have a substantive effect on a person somewhat or strongly supporting increasing fossil fuel taxes.

\subsection{Amplification}

Figure 5 provides visual evidence of an amplifying effect of political orientation for self-transcendence and conservation values. For conservation values, there are no differences in the likelihood of somewhat or strongly favoring increased fossil fuels taxes between people on the political right, but this substantively increases as people move to the political left, particularly for those with small quantities of conservation values. Similarly, for self-transcendence values, there are greater differences for people on the political left than on the political right, providing evidence of an amplifying effect when values and political orientations are in alignment. As such, we find some evidence in support of Hypothesis 3c.

\section{Robustness Checks}

\subsection{Mediation Analyses}

An alternate model to consider is that political orientation mediates the effects of values rather than moderates them. Interaction-based moderation analysis inves- 
tigates if the effect of $x$ on $y$ changes due to a third variable $z$ whereas mediation analysis aims to understand if and how the effect of $x$ on $y$ is due to political orientation itself. Within mediation analyses, the 'total effects' of $x$ on $y$ is commonly decomposed into the 'indirect effects' of $x$ on $y$ via $z$, to see how much of the effect is directly and indirectly attributable to each variable. Due to scaling issues, standard mediation techniques cannot be directly translated to non-linear regression models. A relatively new approach, commonly known as khb, resolves many of these issues, allowing for decomposition of direct and indirect effects in logistic regression models (Karlson et al., 2012; Breen et al., 2013, 2018). Performance analyses of the khb method suggest that the khb routine produces a reasonable approximation of mediation effects under almost all conditions (Smith et al., 2019). Therefore, we investigate for mediating effects by decomposing the direct and indirect effects separately for political orientation by human values on each of the three dependent variables as a robustness check, displayed in Table 3.

Overall, there is very minimal evidence of a mediating effect of any of the human values dimensions by political orientation on climate change concern. The most substantial effect appears to be for openness, where $22 \%$ of the direct effect is confounded by political orientation, but this is largely due to the relatively small size of the effect of openness, where the difference in coefficients before and after the inclusion of political orientation is minimal ( $b=-0.01$,n.s.). Furthermore, we find little evidence of a mediating effect of any of the human values dimensions by political orientation for reducing energy. Lastly, we find limited evidence of political orientation as a mediator of self-transcendence values on support for increased fossil fuel taxes. Roughly $28 \%$ of the effect of self-transcendence is mediated by political orientation, a substantive amount, but the difference in coefficients is not significant ( $b=0.05, n . s$.$) . Accordingly, we find little evidence that values are$ mediated by political orientations. Rather, the effect of values appears to be direct on climate change attitudes and behaviors.

\subsection{Sensitivity Analyses}

Next, as a robustness check against potential forms of bias, we adopt a methodology developed by Frank Frank (2000) and Frank et al. Frank et al. (2013) to estimate how much bias is required in the estimate of a coefficient to invalidate an inference. For these analyses, we will only focus on the robustness of significant indicators displayed in Table 4. To render the effect of self-transcendence on climate change concern non-significant roughly $92 \%$ of the cases would have to be replaced with a case of no effect. As such, the ESS would have to contain an enormous amount of measurement error for this effect to be erroneous. 
Table 3: Decomposition of Value Dimensions by Political Orientation

\begin{tabular}{|c|c|c|c|}
\hline & $\begin{array}{c}\text { Climate Change } \\
\text { Concern }\end{array}$ & $\begin{array}{l}\text { Reduce } \\
\text { Energy }\end{array}$ & $\begin{array}{c}\text { Increase Fossil } \\
\text { Fuel Taxes }\end{array}$ \\
\hline \multicolumn{4}{|l|}{ Self-Transcendence } \\
\hline Reduced & $\begin{array}{l}0.68^{* *} \\
(0.03)\end{array}$ & $\begin{array}{l}0.54^{* *} \\
(0.02)\end{array}$ & $\begin{array}{l}0.19^{* *} \\
(0.02)\end{array}$ \\
\hline Full & $\begin{array}{l}0.63^{* *} \\
(0.03)\end{array}$ & $\begin{array}{l}0.53^{* *} \\
(0.02)\end{array}$ & $\begin{array}{l}0.13^{* *} \\
(0.02)\end{array}$ \\
\hline Difference & $\begin{array}{c}0.05 \\
(0.04)\end{array}$ & $\begin{array}{c}0.01 \\
(0.01)\end{array}$ & $\begin{array}{c}0.05 \\
(0.04)\end{array}$ \\
\hline \multicolumn{4}{|l|}{ Self-Enhancement } \\
\hline Reduced & $\begin{array}{c}-0.12^{* *} \\
(0.02)\end{array}$ & $\begin{array}{c}-0.27^{* *} \\
(0.02)\end{array}$ & $\begin{array}{c}0.02 \\
(0.02)\end{array}$ \\
\hline Full & $\begin{array}{c}-0.12^{* *} \\
(0.02)\end{array}$ & $\begin{array}{c}-0.27^{* *} \\
(0.02)\end{array}$ & $\begin{array}{c}0.02 \\
(0.02)\end{array}$ \\
\hline Difference & $\begin{array}{l}-0.00 \\
(0.03)\end{array}$ & $\begin{array}{l}-0.00 \\
(0.01)\end{array}$ & $\begin{array}{l}-0.00 \\
(0.04)\end{array}$ \\
\hline \multicolumn{4}{|l|}{ Openness } \\
\hline Reduced & $\begin{array}{l}0.05^{*} \\
(0.02)\end{array}$ & $\begin{array}{l}0.16^{* *} \\
(0.02)\end{array}$ & $\begin{array}{l}-0.01 \\
(0.02)\end{array}$ \\
\hline Full & $\begin{array}{l}0.06^{* *} \\
(0.02)\end{array}$ & $\begin{array}{l}0.16^{* *} \\
(0.02)\end{array}$ & $\begin{array}{c}0.00 \\
(0.02)\end{array}$ \\
\hline Difference & $\begin{array}{l}-0.01 \\
(0.03)\end{array}$ & $\begin{array}{l}-0.00 \\
(0.01)\end{array}$ & $\begin{array}{l}-0.01 \\
(0.04)\end{array}$ \\
\hline \multicolumn{4}{|l|}{ Conservation } \\
\hline Reduced & $\begin{array}{c}-0.14^{* *} \\
(0.02)\end{array}$ & $\begin{array}{l}0.05^{* *} \\
(0.02)\end{array}$ & $\begin{array}{c}-0.23^{* *} \\
(0.02)\end{array}$ \\
\hline Full & $\begin{array}{c}-0.12^{* *} \\
(0.02)\end{array}$ & $\begin{array}{l}0.06^{* *} \\
(0.02)\end{array}$ & $\begin{array}{c}-0.20^{* *} \\
(0.02)\end{array}$ \\
\hline Difference & $\begin{array}{l}-0.03 \\
(0.04)\end{array}$ & $\begin{array}{l}-0.01 \\
(0.01)\end{array}$ & $\begin{array}{l}-0.03 \\
(0.04)\end{array}$ \\
\hline \multicolumn{4}{|c|}{ Confounding Percentage } \\
\hline Self-Transcendence & 7.1 & 2.5 & 27.8 \\
\hline Self-Enhancement & 2.4 & 0.3 & -17.6 \\
\hline Openness & -22.5 & -1.9 & 115.5 \\
\hline Conservation & 18.2 & -13.7 & 12.1 \\
\hline
\end{tabular}

Standard errors in parentheses

${ }^{*} p<0.05,{ }^{* *} p<0.01$

In contrast, the comparatively smaller effect of openness to change values on climate change concern would have to have roughly $41 \%$ of the cases replaced with no effect to become non-significant. This finding suggests, the effect of openness is comparatively more vulnerable to measurement error. This also matches with the findings of comparatively diminished substantive effect openness to change values 
as well, where there are minor differences between low and high quantities of this value on climate change concern.

In sum, the larger substantive effects all appear to be very robust, while some of the smaller substantive effects of values may be more vulnerable. As such, caution should be taken when making inferences about values with comparatively smaller effects sizes.

Furthermore, as a robustness check on the interaction product term for the relationship between the four human values dimensions and political orientations, we performed supplementary analyses included models where the four values dimension were further interacted by all control variables (see Hastings and Roeser, 2020). In all the supplementary models, the substantive effect of the interactions remains unchanged, providing evidence that these are not the product of another moderation. Therefore, we find evidence of robustness in these effects.

Table 4: Impact of a Confounding Variable on Key Predictors

\begin{tabular}{lccc}
\hline \hline & $\begin{array}{c}\text { Climate Change } \\
\text { Concern }\end{array}$ & $\begin{array}{c}\text { Reduce } \\
\text { Energy }\end{array}$ & $\begin{array}{c}\text { Increase Fossil } \\
\text { Fuels Tax }\end{array}$ \\
\hline Self-transcendence & $92.7 \%^{*}$ & $91.5 \%^{*}$ & $71.6 \%^{*}$ \\
Self-enhancement & $53.6 \%^{*}$ & $89.2 \%^{*}$ & $34.9 \%$ \\
Openness & $41.1 \%^{*}$ & $75.9 \%^{*}$ & $32.8 \%$ \\
Conservation & $74.8 \%^{*}$ & $62.6 \%^{*}$ & $82.4 \%^{*}$ \\
Political Orientation & $68.6 \%^{*}$ & $28.9 \%^{*}$ & $83.9 \%^{*}$ \\
\hline \hline
\end{tabular}

*Regression coefficient has $p<0.05$ (see Table 2)

\section{Conclusion}

This paper explores how human values and political orientations combine to pattern climate change attitudes and behaviors in Western European states. We build upon the long-standing literature of cross-national climate change attitudes and behaviors to develop a richer understanding of the direct effects of human values and political orientations (McCright et al., 2016b; Lewis et al., 2018; Poortinga et al., 2019; Smith and Mayer, 2018a; Marquart-Pyatt et al., 2019). Further, we uniquely contribute an analysis of the interactive role of human values and political orientations shaping climate change attitudes and behaviors, exploring patterns of amplification. The findings demonstrate the deeply interrelated nature of human values and politics and how their alignment can amplify individual perceptions and actions in relation to climate change. 
We show that human values dimensions have a direct effect on climate change concern, behaviors and policy support. Self-transcendence values have the most substantive (positive) effect on climate change concern and energy reducing behaviors, while being comparatively less effective in shaping support for increased fossil fuel taxes. Rather, conservation values appear to be stronger substantive (negative) drivers of this measure of policy support. These findings are consistent with the prior literature (Poortinga et al., 2019; Dietz et al., 2007). Furthermore, we find that political orientation (moving from right to left) has a substantive positive effect on climate change policy support and concern, but not on individual energy behaviors. These findings provide additional evidence of differences based upon political orientation (McCright et al., 2016b; Lewis et al., 2018; Smith and Mayer, 2018a), but also demonstrate how the effect varies substantially across types of climate change attitudes and behaviors in Western European states.

The principal contribution of this analysis is an exploration of the interactive relationship between human values and political factors. Given that human values and political factors are both substantive predictors of climate change attitudes and behaviors (Hornsey et al., 2016), and deeply related constructs (Caprara and Zimbardo, 2004; Feldman, 2003), we anticipated these factors interact and strengthen support for, or opposition to, climate change concern and behaviors. We find strong evidence of an interactive effect between human values and political orientation. The moderating effect of political orientation was most evident for self-transcendence, where the effect of this value was amplified as people move from the political right to left and greatly increased the likelihood of climate change concern and support for policies that mitigate climate change and support increasing fossil fuel tax to reduce climate change. Openness to change was also moderated by political orientations for climate change concern and policy support as well as support for reducing their energy in a similar direction, but this effect was less pronounced.

Given the adoption of an interactive product term, these findings are reflective of the multiplicative property of positive relationships. They are also consistent with literature on cognitive consistency which posits that individuals have a strong desire for their beliefs, opinions, and attitudes to be congruent(Gawronski, 2012; Quine and Ullian, 1978). As such, when human values aligns with a person's political orientation, this acts as a fortifying mechanism on the validity of one's beliefs, amplifying their attitudes towards climate change via increased, mutually reinforced confidence in the correctness of their position.

In sum, the effects values and political factors on climate change attitudes and behaviors is best represented within an multiplicative interactive relationship, and 
not an additive one, where these moderating factors can strongly amplify climate change support.

The findings have a number of important implications for climate change advocates and policy stakeholders. Advocacy efforts are found to be more effective in increasing problem awareness when they connect with salient values. Frames play an important role in this as they can align values with specific issues. Frames are principles of cognition that function to organize experience and guide action (Benford and Snow, 2000; Goffman, 1974). They do so in part by making "certain aspects of perceived reality more salient in such a way as to promote a particular problem definition, causal interpretation, moral evaluation and treatment recommendation" (Entman, 1993, p.52). Framing efforts are found to be most effective in mobilizing actors when they resonate with a person's values and political ideologies (Chong and Druckman, 2013; Jasper, 1997). Left-leaning political stakeholders could potentially motivate greater support and action by framing their climate change efforts directly in relation the self-transcendence value dimensions. By bringing values, political ideologies and climate change attitudes and behaviors into alignment, there is great potential to shift attitudes and behaviors towards greater climate change support.

There is also greater potential for changing the priorities of existing institutions. Political actors are particularly responsive to shifting public opinions (Soroka and Wlezien, 2010). Substantive, rapid shifts in attitudes have the potential to punctuate "sticky" institutions resulting in shift to policy regimes (Baumgartner and Jones, 2010). In times where climate change becomes a salient political issue, shifting public opinion dynamics presents a "policy window", where climate policy entrepreneurs are provided the opportunity to promote their preferred policy instruments (Kingdon, 1995). Accordingly, the individual-level amplification of climate change attitudes presents an opportunity to shift existing policy structures.

In addition to highlighting potential social mechanisms for promoting climate change concern and action, this study also contributes to the relevant literature by adopting multiple measures approach towards understanding different forms of climate change attitudes and behaviors (Stern, 2000). The effect of human values dimensions and political factors are found to vary substantially across the three dimensions included in this analysis. Political orientation appears to be most effective in shaping support for climate change policies, where people on the political left have a 0.12 higher predicted probability of supporting increases to fossil fuel taxes than those on the left. This effect does appear to be more moderate for climate change concerns (a difference in predicted probability of 0.09 ) and substantively null for energy reducing behaviors. These results suggest that while differences emerge as a result of political orientations, these factors are more closely related 
to matters of policy, but not to individual environmental behaviors. Using the 2016 ESS, but relying upon different indicators, Marquart-Pyatt et al. Marquart-Pyatt et al. (2019) similarly report differences in energy policy support but in energy behavioral intentions. As such, we argue future research needs to pay closer attention to how the effects of key predictors can vary across different forms of climate change attitudes and behaviors (Smith et al., 2018).

The results of this study are limited by the regionality of data from Western European states. The 2016 ESS presents a unique, cross-national dataset, allowing for such comparisons to be made within these states. To better understand the interrelationship between human values and political factors, items for human values should be included in other major cross-national surveys to validate these findings. These results should also be compared to other regions, such as Englishspeaking states, there a strong effect of political factors have been identified, but also in states where political factors have been noted as not being as effective, such as post-Communist, transition states. Further, the role of other contextual factors, such as media influence, climate vulnerability, socio-political histories, should be included in subsequent analysis. 
Acknowledgements We would like to thank Michael Lacy, Pat Hastings, Stephanie Malin and Elissa Braunstein for their comments and feedback on this manuscript.

\section{Declarations}

Funding Keith Smith was partially financially supported by the Leibniz Association (SAW-2017-PIK-4).

Conflicts of interest The authors declare that they have no conflict of interest.

Data Availability This project adopts data collected and made publicly available from the European Social Survey (2016, Wave 8). All ESS data is available at: https://www.europeansocialsurvey.org/data/round-index.html

Replication Materials Stata code to replicate these analyses is available in Keith Smith's github repository https://github.com/edksmith/Replication_ data/tree/main/Values_politics.

Authors' Contributions KS designed the project, analysed all data. KS and LMH drafted the manuscript.

Ethical Declarations This analysis relies upon publically available secondary survey data, sourced from the European Social Survey. Information on the European Social Survey's reserach ethics are available at https://www . europeansocialsurvey . org/about/ethics.html. As this research did not involve human subjects, we did not seek ethics approval for this project. 


\section{References}

Amrhein V, Greenland S, McShane B (2019) Scientists rise up against statistical significance. Nature 567(7748):305, DOI 10.1038/d41586-019-00857-9, URL http://www . nature.com/articles/d41586-019-00857-9

Aspelund A, Lindeman M, Verkasalo M (2013) Political Conservatism and Left-Right Orientation in 28 Eastern and Western European Countries. Political Psychology 34(3):409-417, URL https://www.jstor.org/stable/23481169

Auyero J, Swistun D (2008) The Social Production of Toxic Uncertainty. American Sociological Review 73(3):357-379, DOI 10.1177/000312240807300301, URL https : //doi .org/10.1177/000312240807300301

Barnea MF, Schwartz SH (1998) Values and Voting. Political Psychology 19(1):1740, URL https://www.jstor.org/stable/3792112

Baumgartner FR, Jones BD (2010) Agendas and instability in American politics. University of Chicago Press, Chicago

Benford RD, Snow DA (2000) Framing processes and social movements: An overview and assessment. Annual Review of Sociology 26(1):611-639, DOI 10.1146/annurev.soc.26.1.611, URL https://doi.org/10.1146/annurev.soc. 26. 1.611, https://doi.org/10.1146/annurev.soc.26.1.611

Brambor T, Clark WR, Golder M (2006) Understanding Interaction Models: Improving Empirical Analyses. Political Analysis 14(1):63-82, DOI 10.1093/pan/mpi014, URL https:// www . cambridge.org/core/journals/political-analysis/article/ understanding-interaction-models-improving-empirical-analyses/ 9BA57B3720A303C61EBEC6DDFA40744B

Breen R, Karlson KB, Holm A (2013) Total, Direct, and Indirect Effects in Logit and Probit Models. Sociological Methods \& Research 42(2):164-191, DOI 10. 1177/0049124113494572, URL https://doi.org/10.1177/0049124113494572

Breen R, Karlson KB, Holm A (2018) Interpreting and Understanding Logits, Probits, and Other Nonlinear Probability Models. Annual Review of Sociology 44(1):39-54, DOI 10.1146/annurev-soc-073117-041429, URL https://doi.org/ 10.1146/annurev-soc-073117-041429

Brewer M, Brown R (1998) Intergroup Relations. In: Gilbert D, Fiske S, Lindzey G (eds) Handbook of Social Psychology, vol 2, 4th edn, McGraw-Hill, Boston, pp 554-594

Brulle RJ, Carmichael J, Jenkins JC (2012) Shifting public opinion on climate change: an empirical assessment of factors influencing concern over climate change in the U.S., 2002-2010. Climatic Change 114(2):169-188, DOI 10. 1007/s10584-012-0403-y, URL https://link.springer.com/article/10.1007/ s10584-012-0403-y

Campbell TH, Kay AC (2014) Solution aversion: On the relation between ideology and motivated disbelief. Journal of Personality and Social Psychology 107(5):809-824

Caprara GV, Zimbardo PG (2004) Personalizing politics: a congruency model of political preference. The American Psychologist 59(7):581-594, DOI 10.1037/ 0003-066X.59.7.581

Caprara GV, Schwartz S, Capanna C, Vecchione M, Barbaranelli C (2006) Personality and Politics: Values, Traits, and Political Choice. Political Psychology 27(1):1-28, DOI 10.1111/j.1467-9221.2006.00447.x, URL https:// 
onlinelibrary.wiley.com/doi/abs/10.1111/j.1467-9221.2006.00447.x

Caprara GV, Vecchione M, Schwartz SH, Schoen H, Bain PG, Silvester J, Cieciuch J, Pavlopoulos V, Bianchi G, Kirmanoglu H, Baslevent C, Mamali C, Manzi J, Katayama M, Posnova T, Tabernero C, Torres C, Verkasalo M, Lönnqvist JE, Vondráková E, Caprara MG (2017) Basic Values, Ideological Self-Placement, and Voting: A Cross-Cultural Study. Cross-Cultural Research 51(4):388-411, DOI 10.1177/1069397117712194, URL https://doi.org/ $10.1177 / 1069397117712194$

Chong D, Druckman JN (2013) Counterframing Effects. The Journal of Politics 75(1):1-16, DOI 10.1017/S0022381612000837, URL https://www. journals . uchicago.edu/doi/abs/10.1017/S0022381612000837, publisher: The University of Chicago Press

Cohen G (2003) Party Over Policy: The Dominating Impact of Group Influence on Political Beliefs. Journal of Personality and Social Psychology 85(5):808-822

Colvin RM, Witt GB, Lacey J (2015) The social identity approach to understanding socio-political conflict in environmental and natural resources management. Global Environmental Change 34:237-246, DOI 10.1016/j. gloenvcha.2015.07.011, URL http://www.sciencedirect.com/science/article/ $\mathrm{pii} / \mathrm{S} 0959378015300182$

Converse P (1964) The Nature of Belief Systems in Mass Publics. In: Ideology and Discontent, Free Press, Glencoe, IL

Corner A, Markowitz E, Pidgeon N (2014) Public engagement with climate change: the role of human values. Wiley Interdisciplinary Reviews: Climate Change 5(3):411-422, DOI 10.1002/wcc.269, URL https://onlinelibrary.wiley.com/ doi/abs/10.1002/wcc. 269

Davidov E (2008) A cross-country and cross-time comparison of the human values measurements with the second round of the European Social Survey. Survey Research Methods 2(1):33-46, DOI info:doi/10.5167/uzh-95236, URL https:// ojs.ub.uni-konstanz.de/srm/article/view/365, conference Name: Survey Research Methods Meeting Name: Survey Research Methods Number: 1 Publisher: European Survey Research Association

Davidov E, Schmidt P, Schwartz SH (2008) Bringing Values Back InThe Adequacy of the European Social Survey to Measure Values in 20 Countries. Public Opinion Quarterly 72(3):420-445, DOI 10.1093/poq/nfn035, URL https: //academic.oup.com/poq/article/72/3/420/1837853

Dietz T, Fitzgerald A, Shwom R (2005) Environmental Values. Annual Review of Environment and Resources 30(1):335-372, DOI 10.1146/annurev.energy. 30.050504.144444, URL https://doi.org/10.1146/annurev.energy.30.050504. 144444

Dietz T, Dan A, Shwom R (2007) Support for Climate Change Policy: Social Psychological and Social Structural Influences*. Rural Sociology 72(2):185214, DOI 10.1526/003601107781170026, URL http://onlinelibrary.wiley. com/doi/10.1526/003601107781170026/abstract

Drews S, Bergh JCJMvd (2016) What explains public support for climate policies? A review of empirical and experimental studies. Climate Policy 16(7):855-876, DOI 10.1080/14693062.2015.1058240, URL https://doi.org/ $10.1080 / 14693062.2015 .1058240$

Egan PJ, Mullin M (2017) Climate Change: US Public Opinion. Annual Review of Political Science 20(1):209-227, DOI 10.1146/annurev-polisci-051215-022857, 
URL https://doi.org/10.1146/annurev-polisci-051215-022857, _eprint: https://doi.org/10.1146/annurev-polisci-051215-022857

Engels A, Hüther O, Schäfer M, Held H (2013) Public climate-change skepticism, energy preferences and political participation. Global Environmental Change 23(5):1018-1027, DOI 10.1016/j.gloenvcha.2013.05.008, URL http:// www.sciencedirect.com/science/article/pii/S0959378013000824

Entman RM (1993) Framing: Toward clarification of a fractured paradigm. Journal of Communication 43(4):51-58

European Social Survey (2016a) ESS8 - 2016 Documentation Report. Tech. rep., Norwegian Centre for Research Data, Norway

European Social Survey (2016b) European Social Survey Round 8 Data: Edition 2.0. Tech. rep., Norwegian Centre for Research Data, Norway

Fairbrother M, Johansson Sevä I, Kulin J (2019) Political trust and the relationship between climate change beliefs and support for fossil fuel taxes: Evidence from a survey of 23 European countries. Global Environmental Change 59:102003, DOI 10.1016/j.gloenvcha.2019.102003, URL http://www. sciencedirect.com/science/article/pii/S095937801831238X

Farmer JD, Hepburn C, Ives MC, Hale T, Wetzer T, Mealy P, Rafaty R, Srivastav S, Way $R$ (2019) Sensitive intervention points in the post-carbon transition. Science 364(6436):132-134, DOI 10.1126/science.aaw7287, URL https: //science.sciencemag. org/content/364/6436/132

Farrell J (2016) Corporate funding and ideological polarization about climate change. Proceedings of the National Academy of Sciences 113(1):92-97, DOI 10.1073/pnas.1509433112, URL http://www.pnas.org/content/113/1/92

Feinberg M, Willer R (2011) Apocalypse Soon?: Dire Messages Reduce Belief in Global Warming by Contradicting Just-World Beliefs. Psychological Science 22(1):34-38, DOI 10.1177/0956797610391911, URL https://doi.org/10.1177/ 0956797610391911

Feinberg M, Willer R (2013) The Moral Roots of Environmental Attitudes. Psychological Science 24(1):56-62, DOI 10.1177/0956797612449177, URL https: //doi.org/10.1177/0956797612449177, publisher: SAGE Publications Inc

Feldman L, Maibach EW, Roser-Renouf C, Leiserowitz A (2012) Climate on Cable: The Nature and Impact of Global Warming Coverage on Fox News, CNN, and MSNBC. The International Journal of Press/Politics 17(1):3-31, DOI 10.1177/ 1940161211425410, URL https://doi.org/10.1177/1940161211425410

Feldman S (1988) Structure and Consistency in Public Opinion: the Role of Core Beliefs and Values. American Journal of Political Science 32(2):416-440, DOI 10.2307/2111130, URL https://www.jstor.org/stable/2111130

Feldman S (2003) Values, ideology, and the structure of political attitudes. In: Sears D, Huddy L, Jervis R (eds) Oxford Handbook of Political Psychology, Oxford University Press, New York, pp 477-508

Festinger L (1957) A theory of cognitive dissonance. Row and Peterson, Evanston, IL

Frank KA (2000) Impact of a Confounding Variable on a Regression Coefficient. Sociological Methods \& Research 29(2):147-194, DOI 10.1177/ 0049124100029002001, URL https://doi.org/10.1177/0049124100029002001, publisher: SAGE Publications Inc

Frank KA, Maroulis SJ, Duong MQ, Kelcey BM (2013) What Would It Take to Change an Inference? Using Rubin's Causal Model to Interpret the Ro- 
bustness of Causal Inferences. Educational Evaluation and Policy Analysis 35(4):437-460, DOI 10.3102/0162373713493129, URL https://doi.org/10. 3102/0162373713493129, publisher: American Educational Research Association

Gardiner SM (2006) A Perfect Moral Storm: Climate Change, Intergenerational Ethics and the Problem of Moral Corruption. Environmental Values 15(3):397413, DOI 10.3197/096327106778226293

Gawronski B (2012) Back to the Future of Dissonance Theory: Cognitive Consistency as a Core Motive. Social Cognition 30(6):652-668, DOI 10.1521/soco.2012. 30.6.652, URL https://guilfordjournals.com/doi/abs/10.1521/soco.2012.30. 6.652, publisher: Guilford Publications Inc.

Gelissen J (2007) Explaining Popular Support for Environmental Protection: A Multilevel Analysis of 50 Nations. Environment and Behavior 39(3):392-415, DOI 10.1177/0013916506292014, URL https://doi.org/10. $1177 / 0013916506292014$

Goffman E (1974) Frame analysis: An essay on the organization of experience. Harvard University Press, Cambridge, MA

Hamilton LC (2011) Education, politics and opinions about climate change evidence for interaction effects. Climatic Change 104(2):231-242, DOI 10. 1007/s10584-010-9957-8, URL https://link.springer.com/article/10.1007/ s10584-010-9957-8

Harring N (2014) Corruption, inequalities and the perceived effectiveness of economic pro-environmental policy instruments: A European cross-national study. Environmental Science \& Policy 39(Supplement C):119-128, DOI 10.1016/j. envsci.2013.08.011, URL http://www.sciencedirect.com/science/article/pii/ S1462901113001603

Hastings OP, Roeser KK (2020) Happiness in Hard Times: Does Religion Buffer the Negative Effect of Unemployment on Happiness? Social Forces DOI 10.1093/sf/soaa018, URL https ://academic .oup.com/sf/advance-article/doi/ $10.1093 / \mathrm{sf} / \mathrm{soaa} 018 / 5810065$

Hitlin S, Piliavin JA (2004) Values: Reviving a Dormant Concept. Annual Review of Sociology 30(1):359-393, DOI 10.1146/annurev.soc.30.012703.110640, URL https://doi.org/10.1146/annurev.soc.30.012703.110640

Hmielowski JD, Feldman L, Myers TA, Leiserowitz A, Maibach E (2014) An attack on science? Media use, trust in scientists, and perceptions of global warming. Public Understanding of Science 23(7):866-883, DOI 10.1177/ 0963662513480091, URL https://doi.org/10.1177/0963662513480091

Hoffman AJ (2011) The growing climate divide. Nature Climate Change 1(4):195196, DOI 10.1038/nclimate1144, URL http://www.nature.com/articles/ nclimate1144, number: 4 Publisher: Nature Publishing Group

Hornsey MJ, Harris EA, Bain PG, Fielding KS (2016) Meta-analyses of the determinants and outcomes of belief in climate change. Nature Climate Change 6(6):622-626, DOI 10.1038/nclimate2943, URL https://www.nature. com/articles/nclimate 2943

Inglehart R (1977) Values, Objective Needs, and Subjective Satisfaction Among Western Publics. Comparative Political Studies 9(4):429-58

Inglehart R (1995) Public Support for Environmental Protection: Objective Problems and Subjective Values in 43 Societies. PS: Political Science \& Politics 28(1):57-72, DOI 10.2307/420583, URL https://www . cambridge.org/core/journals/ps-political-science-and-politics/article/ 
public-support-for-environmental-protection-objective-problems-and-subjective-values-in-43-societies/ A051E18F5DE47D79A3B8C79AC037223B

Iyengar S, Sood G, Lelkes Y (2012) Affect, Not Ideology: A Social Identity Perspective on Polarization. Public Opinion Quarterly 76(3):405-431

Jasper JM (1997) The Art of Moral Protest: Culture, Biography and Creativity in Social Movements. University of Chicago Press, Chicago

Joas H (2000) The Genesis of Values. Polity Press, Cambridge, UK

Jost JT, Glaser J, Kruglanski AW, Sulloway FJ (2003) Political Conservatism as Motivated Social Cognition. Psychological Bulletin 129(3):339-375

Kahan DM (2015) The Politically Motivated Reasoning Paradigm, Part 1: What Politically Motivated Reasoning Is and How to Measure It. Emerging trends in the social and behavioral sciences: An interdisciplinary, searchable, and linkable resource pp 1-16

Kahan DM (2017) 'Ordinary science intelligence': a science-comprehension measure for study of risk and science communication, with notes on evolution and climate change. Journal of Risk Research 20(8):995-1016, DOI 10.1080/13669877. 2016.1148067, URL https://doi.org/10.1080/13669877.2016.1148067

Karlson KB, Holm A, Breen R, Slovic P (2012) Comparing Regression Coefficients Between Same-sample Nested Models Using Logit and Probit: A New Method. Sociological Methodology 42(1):286-313, DOI 10.1177/0081175012444861, URL https ://doi .org/10.1177/0081175012444861

Kasperson RE, Renn O, Slovic P, Brown HS, Emel J, Goble R, Kasperson JX, Ratick S (1988) The Social Amplification of Risk: A Conceptual Framework. Risk Analysis 8(2):177-187, DOI 10.1111/j.1539-6924.1988.tb01168.x, URL http:// onlinelibrary.wiley.com/doi/10.1111/j.1539-6924.1988. tb01168.x/abstract

Katz-Gerro T, Greenspan I, Handy F, Lee HY (2017) The Relationship between Value Types and Environmental Behaviour in Four Countries: Universalism, Benevolence, Conformity and Biospheric Values Revisited. Environmental Values 26(2):223-249, DOI 10.3197/096327117X14847335385599

Kingdon JW (1995) Agendas, alternatives, and public policies. Little, Brown, Boston

Lee TM, Markowitz EM, Howe PD, Ko CY, Leiserowitz AA (2015) Predictors of public climate change awareness and risk perception around the world. Nature Climate Change 5(11):1014-1020, DOI 10.1038/nclimate2728, URL https:// www. nature.com/articles/nclimate2728

Lewis GB, Palm R, Feng B (2018) Cross-national variation in determinants of climate change concern. Environmental Politics 0(0):1-29, DOI 10.1080/09644016. 2018.1512261, URL https://doi.org/10.1080/09644016.2018.1512261

van der Linden S (2015) The social-psychological determinants of climate change risk perceptions: Towards a comprehensive model. Journal of Environmental Psychology 41:112-124, DOI 10.1016/j.jenvp.2014.11.012, URL http://www. sciencedirect.com/science/article/pii/S0272494414001170

Long JS, Freese J (2014) Regression models for categorical dependent variables using Stata, second edition edn. Stata Press, College Station, TX

Malin SA (2015) The Price of Nuclear Power. Rutgers University Press, New Brunswick, N.J.

Malka A, Lelkes Y (2010) More than Ideology: Conservative-Liberal Identity and Receptivity to Political Cues. Social Justice Research 23(2-3):156-188, DOI 10.1007/s11211-010-0114-3, URL https://link.springer.com/article/ 
$10.1007 / \mathrm{s} 11211-010-0114-3$

Marquart-Pyatt ST, Qian H, Houser MK, McCright AM (2019) Climate Change Views, Energy Policy Preferences, and Intended Actions Across Welfare State Regimes: Evidence from the European Social Survey. International Journal of Sociology 49(1):1-26, DOI 10.1080/00207659.2018.1560979, URL https://doi.org/10.1080/00207659.2018.1560979, publisher: Routledge _eprint: https://doi.org/10.1080/00207659.2018.1560979

Mayer A, Smith EK (2018) Unstoppable climate change? The influence of fatalistic beliefs about climate change on behavioural change and willingness to pay crossnationally. Climate Policy 0(0):1-13, DOI 10.1080/14693062.2018.1532872, URL https://doi.org/10.1080/14693062.2018.1532872

McCrea R, Leviston Z, Walker IA (2016) Climate Change Skepticism and Voting Behavior: What Causes What? Environment and Behavior 48(10):13091334, DOI 10.1177/0013916515599571, URL http://dx.doi.org/10.1177/ 0013916515599571

McCright AM, Dunlap RE (2003) Defeating Kyoto: The Conservative Movement's Impact on U.S. Climate Change Policy. Social Problems 50(3):348-373, DOI 10.1525/sp.2003.50.3.348, URL https ://academic .oup.com/socpro/article/50/ 3/348/1617546/Defeating-Kyoto-The-Conservative-Movement-s-Impact

McCright AM, Dunlap RE (2010) Anti-reflexivity. Theory, Culture \& Society 27(23):100-133, DOI 10.1177/0263276409356001, URL https://doi.org/10.1177/ 0263276409356001

McCright AM, Dunlap RE (2011) Cool dudes: The denial of climate change among conservative white males in the United States. Global Environmental Change 21(4):1163-1172, DOI 10.1016/j.gloenvcha.2011.06.003, URL http: //www.sciencedirect.com/science/article/pii/S095937801100104X

McCright AM, Dunlap RE, Marquart-Pyatt ST (2016a) Political ideology and views about climate change in the European Union. Environmental Politics 25(2):338-358, DOI 10.1080/09644016.2015.1090371, URL http://rsa. tandfonline.com/doi/abs/10.1080/09644016.2015.1090371

McCright AM, Marquart-Pyatt ST, Shwom RL, Brechin SR, Allen S (2016b) Ideology, capitalism, and climate: Explaining public views about climate change in the United States. Energy Research \& Social Science 21:180-189, DOI 10.1016/ j.erss.2016.08.003, URL http://www.sciencedirect.com/science/article/pii/ S2214629616301864

Milfont TL, Milojev P, Greaves LM, Sibley CG (2015) Socio-structural and psychological foundations of climate change beliefs. New Zealand Journal of Psychology 44(1):17-30

Mize TD (2019) Best Practices for Estimating, Interpreting, and Presenting Nonlinear Interaction Effects. Sociological Science 6:81-117, DOI 10.15195/v6.a4, URL https://www.sociologicalscience.com/articles-v6-4-81/

Mood C (2010) Logistic regression: Why we cannot do what we think we can do, and what we can do about it. European sociological review 26(1):67-82

Nordlund AM, Garvill J (2002) Value Structures behind Proenvironmental Behavior. Environment and Behavior 34(6):740-756, DOI 10.1177/001391602237244, URL https://doi.org/10.1177/001391602237244, publisher: SAGE Publications Inc

Oreskes N, Conway EM (2011) Merchants of doubt: How a handful of scientists obscured the truth on issues from tobacco smoke to global warming. Bloomsbury 
Publishing USA

Piurko Y, Schwartz SH, Davidov E (2011) Basic Personal Values and the Meaning of Left-Right Political Orientations in 20 Countries. Political Psychology 32(4):537-561, DOI 10.1111/j.1467-9221.2011.00828.x, URL https:// onlinelibrary.wiley.com/doi/abs/10.1111/j.1467-9221.2011.00828.x

Poortinga W, Spence A, Whitmarsh L, Capstick S, Pidgeon NF (2011) Uncertain climate: An investigation into public scepticism about anthropogenic climate change. Global Environmental Change 21(3):1015-1024, DOI 10.1016/j. gloenvcha.2011.03.001, URL http://www.sciencedirect.com/science/article/ pii/S0959378011000288

Poortinga W, Whitmarsh L, Steg L, Böhm G, Fisher S (2019) Climate change perceptions and their individual-level determinants: A cross-European analysis. Global Environmental Change 55:25-35, DOI 10.1016/j.gloenvcha.2019.01.007, URL http://www.sciencedirect.com/science/article/pii/S0959378018305107

Quine W, Ullian J (1978) The web of belief, vol 2. Random House, New York

Rokeach M (1973) The nature of human values. Free Press, New York

Roser-Renouf C, Nisbet MC (2008) The measurement of key behavioral science constructs in climate change research. International Journal of Sustainability Communication 3:37-95

Sabatier PA (1988) An advocacy coalition framework of policy change and the role of policy-oriented learning therein. Policy Sciences 21(2):129-168, DOI 10.1007/BF00136406, URL https://doi.org/10.1007/BF00136406

Schwartz S (2012) An Overview of the Schwartz Theory of Basic Values. Online Readings in Psychology and Culture 2(1), DOI 10.9707/2307-0919.1116, URL https://scholarworks.gvsu.edu/orpc/vol2/iss1/11

Schwartz SH (1992) Universals in the Content and Structure of Values: Theoretical Advances and Empirical Tests in 20 Countries. In: Zanna MP (ed) Advances in Experimental Social Psychology, vol 25, Academic Press, pp 165, DOI 10.1016/S0065-2601(08)60281-6, URL http://www . sciencedirect.com/ science/article/pii/S0065260108602816

Schwartz SH (2003) A Proposal for Measuring Value Orientations Across Nations. Tech. rep., European Social Survey, London, URL https://www. europeansocialsurvey.org/docs/methodology/core_ess_ questionnaire/ESS_core_questionnaire_human_values.pdf

Schwartz SH, Caprara GV, Vecchione M (2010) Basic Personal Values, Core Political Values, and Voting: A Longitudinal Analysis. Political Psychology 31(3):421452, URL https://www. jstor.org/stable/20721300

Smith EK, Mayer A (2018a) Anomalous Anglophones? Contours of free market ideology, political polarization, and climate change attitudes in Englishspeaking countries, Western European and post-Communist states. Climatic Change 152(1):17-34, DOI 10.1007/s10584-018-2332-x, URL https://doi.org/ $10.1007 / \mathrm{s} 10584-018-2332-\mathrm{x}$

Smith EK, Mayer A (2018b) A social trap for the climate? Collective action, trust and climate change risk perception in 35 countries. Global Environmental Change 49:140-153, DOI 10.1016/j.gloenvcha.2018.02.014, URL http: //www.sciencedirect.com/science/article/pii/S0959378017309585

Smith EK, Hempel LM, MacIlroy K (2018) What's 'evangelical' got to do with it? Disentangling the impact of evangelical Protestantism on environmental outcomes. Environmental Politics 27(2):292-319, DOI 10.1080/09644016.2017. 
1384185, URL https://doi.org/10.1080/09644016.2017.1384185

Smith EK, Lacy MG, Mayer A (2019) Performance Simulations for Categorical Mediation: Analyzing khb estimates of mediation in ordinal regression models. Stata Journal pp 1-19, status: forthcoming

Smith N, Leiserowitz A (2012) The rise of global warming skepticism: exploring affective image associations in the United States over time. Risk Analysis: An Official Publication of the Society for Risk Analysis 32(6):1021-1032, DOI 10. $1111 / \mathrm{j} .1539-6924.2012 .01801 . x$

Soroka SN, Wlezien C (2010) Degrees of Democracy: Politics, Public Opinion and Policy. Cambridge University Press, New York

Spence A, Poortinga W, Butler C, Pidgeon NF (2011) Perceptions of climate change and willingness to save energy related to flood experience. Nature Climate Change 1(1):46-49, DOI 10.1038/nclimate1059, URL https://www. nature.com/articles/nclimate1059

Steg L, De Groot JIM (2012) Environmental Values. In: Clayton SD (ed) The Oxford Handbook of Environmental and Conservation Psychology, Oxford University Press, New York, pp 81-92

Stern PC (2000) New Environmental Theories: Toward a Coherent Theory of Environmentally Significant Behavior. Journal of Social Issues 56(3):407-424, DOI 10.1111/0022-4537.00175, URL https://spssi.onlinelibrary.wiley.com/ doi/abs/10.1111/0022-4537.00175

Stern PC, Dietz T, Abel T, Guagnano GA, Kalof L (1999) A Value-Belief-Norm Theory of Support for Social Movements: The Case of Environmentalism. Human Ecology Review 6(2):81-97, URL https://www.jstor.org/stable/24707060

Tajfel H (1978) Social Categorization, Social Identity and Social Comparisons. In: Tajfel H (ed) Differentiation between Social Groups, Academic, London, pp $61-76$

Tesler M (2017) Elite Domination of Public Doubts About Climate Change (Not Evolution). Political Communication 0(0):1-21, DOI 10.1080/10584609.2017. 1380092, URL https://doi.org/10.1080/10584609.2017.1380092

Tranter B, Booth K (2015) Scepticism in a changing climate: A crossnational study. Global Environmental Change 33:154-164, DOI 10.1016/j. gloenvcha.2015.05.003, URL http://www.sciencedirect.com/science/article/ $\mathrm{pii/S0959378015000758}$

Turner JC, Oakes PJ, Haslam SA, McGarty C (1994) Self and Collective: Cognition and Social Context. Personality and Social Psychology Bulletin 20(5):454-463, DOI 10.1177/0146167294205002, URL https://doi.org/10. 1177/0146167294205002, publisher: SAGE Publications Inc

Unsworth KL, Fielding KS (2014) It's political: How the salience of one's political identity changes climate change beliefs and policy support. Global Environmental Change 27:131-137, DOI 10.1016/j.gloenvcha.2014.05.002, URL http://www.sciencedirect.com/science/article/pii/S0959378014000909

Wardekker JA, Petersen AC, van der Sluijs JP (2009) Ethics and public perception of climate change: Exploring the Christian voices in the US public debate. Global Environmental Change 19(4):512-521, DOI 10.1016/j.gloenvcha.2009.07.008, URL http://www.sciencedirect.com/science/article/pii/S0959378009000648

Weible C, Sabatier PA (2017) Theories of the Policy Process, 4th edn. Westview Press, New York 
Weisberg H, Greene S (2003) The Political Psychology of Party Identification. In: MacKuen M, Rabinowitz G (eds) Electoral Democracy, University of Michigan Press, Ann Arbor, MI, pp 83-124

\section{Supplementary Information}

Table S1: Cronbach's $\alpha$ for Scales and items

\begin{tabular}{|c|c|}
\hline & $\begin{array}{l}\text { Cronbach's } \alpha \\
\text { if deleted }\end{array}$ \\
\hline \multicolumn{2}{|l|}{ Self-transcendence } \\
\hline important to help people and care for others well-being & 0.649 \\
\hline important to be loyal to friends and devoted to help people & 0.660 \\
\hline important that people are treated equally and have equal opportunities & 0.677 \\
\hline important to understand different people & 0.665 \\
\hline important to care for nature and environment & 0.691 \\
\hline Overall Cronbach's $\alpha$ & 0.716 \\
\hline \multicolumn{2}{|l|}{ Self-enhancement } \\
\hline important to have a good time & 0.704 \\
\hline important to seek fun and things that give pleasure & 0.706 \\
\hline important to show abilities and be admired & 0.659 \\
\hline important to be successful and that people recognize achievements & 0.642 \\
\hline important to be rich, have money and expensive things & 0.688 \\
\hline important to get respect from others & 0.700 \\
\hline Overall Cronbach's $\alpha$ & 0.722 \\
\hline \multicolumn{2}{|l|}{ Openness to Change } \\
\hline important to think new ideas and being creative & 0.575 \\
\hline important to make own decisions and be free & 0.629 \\
\hline important to try new and different things in life & 0.476 \\
\hline important to seek adventures and have an exciting life & 0.553 \\
\hline Overall Cronbach's $\alpha$ & 0.633 \\
\hline \multicolumn{2}{|l|}{ Conservation } \\
\hline important to live in secure and safe surroundings & 0.653 \\
\hline important that government is strong and secures safety & 0.659 \\
\hline important to do what is told and follow rules & 0.670 \\
\hline important to behave properly & 0.640 \\
\hline important to be humble and modest, not draw attention & 0.691 \\
\hline important to follow traditions and customs & 0.677 \\
\hline Overall Cronbach's $\alpha$ & 0.704 \\
\hline \multicolumn{2}{|l|}{ Political Trust } \\
\hline Trust in country's parliament & 0.834 \\
\hline Trust in the legal system & 0.856 \\
\hline Trust in politicians & 0.830 \\
\hline Trust in political parties & 0.838 \\
\hline Overall Cronbach's $\alpha$ & 0.878 \\
\hline
\end{tabular}

